\title{
Analisis Fakor Internal dan Eksternal yang Memengaruhi Financial Distress Bank Umum Syariah Periode 2014-2018
}

\author{
Analysis of internal and external factors influencing financial distress of Islamic commercial bank \\ period 2014-2018
}

\section{Dhiwi Rasa Wulan Pamungkas}

Program Studi D4 Keuangan Syariah, Politeknik Negeri Bandung

E-mail:dhiwirasa@gmail.com

\section{Fatmi Hadiani}

Jurusan Akuntansi, Politeknik Negeri Bandung

E-mail: fatmihadiani10@gmail.com

\section{Radia Purbayati}

Jurusan Akuntansi, Politeknik Negeri Bandung

E-mail: radia.purbayati@polbna.ac.id

\begin{abstract}
The purpose of this study is to determine the influence of Non Performing Finance (NPF), Financing to Deposit Ratio (FDR), Capital Adequacy Ratio (CAR), Inflation, and Gross Domestic Product (GDP) on FinancialDistress as measured by Grover method (G-Score). The sample of this study used a purposive sampling method and obtained 12 Islamic Commercial Banks in Indonesia to be analyzed. The data in this study were sourced from annual report Islamic Banks and reports on inflation and Gross Domestic Product (GDP). This research will be analyzed by a logistic regression model that will be tested using the EViews version $10 \mathrm{SV}$ software. The results of this study indicate that there are four Islamic Commercial Banks in Indonesia that experienced financial distress during the 2014-2018 period. Partially, NPF and inflation bave a significant effect on financial distress, while FDR, CAR, and GDP haveno significanteffect on financial distress.
\end{abstract}

Keywords: financial distress, NPF, FDR, CAR, inflation, GDP

\section{Pendahuluan}

Krisis ekonomi yang terjadi di Indonesia pada tahun 1997 dimulai dengan melemahnya nilai tukar rupiah. Keadaan ini semakin memburuk di tahun 1998 yang ditandai dengan inflasi yang mencapai 78\%, sehingga menyebabkan suku bunga semakin tinggi (Machmud \& Rukmana, 2010). Hal ini membuat kondisi ekonomi di Indonesia menjadi tidak stabil dan menyebabkan banyak bank diambang kebangkrutan karena mengalami negative spread, masalah likuiditas, fluktuasi nilai tukar yang tajam, masalah NPL (Non-Performing Loan), dan modal bank yang semakin rendah (Amin, 2004).

Menurut Muhammad (2005), sebelum terjadi krisis ekonomi terdapat 240 bank di Indonesia, namun setelah krisis ekonomi terjadi hanya sekitar 73 bank yang bertahan, sementara bank lainnya harus melakukan restrukturisasi dan penyehatan yang menyedot biaya yang ditanggung oleh rakyat melalui APBN. Salah satu bank yang bertahan adalah Bank Muamalat Indonesia (Amin, 2004). Hal ini terjadi karena bank syariah tidak berbasis pada bunga, sehingga bebas dari negative spread (Muhammad, 2005). Akan tetapi, hal tersebut tidak menutupi risiko yang mungkin muncul dan akan 
menimbulkan kebangkrutan bank syariah. Di mana risiko ini dapat berupa hambatan dari faktor internal dan eksternal bank syariah.

Faktor internal yang dapat mempengaruhi terjadinya potensi kebangkrutan adalah NPF (Non Performing Finance), FDR (Financing to Deposit Ratio), dan CAR (Capital Adequacy Ratio). Berikut adalah rasio NPF, FDR, dan CAR dari tahun 2014 hingga 2018.

Tabel 1. Rasio NPF, FDR, dan CAR Bank Umum Syariah

\begin{tabular}{|c|c|c|c|}
\hline Tahun & NPF (\%) & FDR (\%) & CAR (\%) \\
\hline 2014 & 4,95 & 86,66 & 15,74 \\
\hline 2015 & 4,84 & 88,03 & 15,02 \\
\hline 2016 & 4,42 & 85,99 & 16,63 \\
\hline 2017 & 4,76 & 79,61 & 17,91 \\
\hline 2018 & 3,26 & 78,53 & 20,39 \\
\hline
\end{tabular}

Sumber: Statistika Perbankan Syariah

Dapat dilihat bahwa rasio NPF terjadi penurunan dari tahun 2014 hingga 2018. Hal ini menunjukan bahwa besar pembiayaan bermasalah yang dimiliki bank syariah semakin menurun. Akan tetapi, di tahun 2017 besar rasio NPF hampir mendekati 5\%, sedangkan menurut ketentuan rasio NPF ini tidak boleh melebihi 5\% karena dapat memicu terjadinya kebangkrutan. Oleh karena itu, bank syariah harus tetap berhati-hati karena rasio NPF bisa naik apabila tidak dijaga dengan sebaik mungkin.

Besar FDR bank syariah terjadi penurunan di tahun 2018 sebesar 1,08\% dari tahun 2017. Menurut Rivai, dkk (2007), semakin tinggi FDR akan berdampak pada meningkatnya profitabilitas karena jumlah pembiayaan yang disalurkan meningkat. Oleh karena itu, bank syariah harus mampu menjaga FDR tetap meningkat, akan tetapi tidak melebihi 110\% karena melebihi dana yang dihimpun. FDR yang terlalu tinggi akan mengakibatkan menurunnya likuiditas bank tersebut karena berkurangnya dana yang dihimpun, sehingga akan menghambat kegiatan operasional bank dan berpotensi terjadinya kebangkrutan. Secara keseluruhan, Bank Umum Syariah telah menyalurkan $78,53 \%$ dari dana yang dihimpun dalam bentuk pembiayaan di tahun 2018. Walaupun besarFDR tersebut masih di batas kewajaran, akan tetapi bank syariah harus menjaganya tetap berada di batas aman untuk menghindari potensikebangkrutan.

Besar CAR juga mengalami peningkatan dari tahun 2014 hingga 2018 sebesar 4,65\%. Peningkatan ini menunjukkan kemampuan bank syariah dalam menutupi aktiva berisiko dengan modal sendiri semakin membaik. Walaupun CAR telah memenuhi batas minimum, yaitu sebesar $8 \%$, tetapi CAR yang terlalu tinggi menunjukkan bahwa bank tersebut tidak memanfaatkan aktiva berisiko dalam memperoleh pendapatan, sehingga bank tidak menghasilkan laba yang optimal dan akan menurunkan tingkat kesehatan bank.

Faktor eksternal bank syariah yang dapat mempengaruhi potensi terjadinya kebangkrutan adalah inflasi dan Produk Domestik Bruto (PDB). Berikut merupakan pertumbuhan Inflasi dan PDB di Indonesia dari tahun 2014 hingga 2018.

Tabel 2. Tingkat Inflasi dan Pertumbuhan PDB di Indonesia

\begin{tabular}{|c|c|c|}
\hline $\begin{array}{c}\text { TAHU } \\
\mathbf{N}\end{array}$ & INFLASI (\%) & PDB (\%) \\
\hline 2014 & 8,4 & 5,0 \\
\hline 2015 & 3,4 & 4,8 \\
\hline 2016 & 3,0 & 5,0 \\
\hline
\end{tabular}




\begin{tabular}{|c|c|c|}
\hline 2017 & 3,6 & 5,1 \\
\hline 2018 & 3,1 & 5,2 \\
\hline
\end{tabular}

Dapat dilihat bahwa laju inflasi dari tahun 2014 hingga 2018 semakin membaik. Hal ini ditunjukkan dengan menurunnya tingkat inflasi dari tahun 2014 hingga 2018. Penurunan tingkat inflasi ini diikuti dengan pertumbuhan PDB yang menunjukkan bahwa secara umum pembangunan ekonomi di Indonesia semakin membaik. Penurunan tingkat inflasi dan pertumbuhan PDB ini beriringan dengan penurunan NPF dan FDR, serta kenaikan CAR. Hal ini mendukung pandangan kaum 'neo-liberal' yang mengatakan bahwa pembangunan ekonomi dipengaruhi juga oleh pembangunan sektor finansial (Kuncoro \& Suhardjono, 2011). Oleh karena itu, potensi terjadinya kebangkrutan dipengaruhi juga oleh kinerja ekonomi suatu negara.

Akan tetapi, beberapa penelitian menunjukkan hasilyang berbeda dengan pernyataan diatas. Di mana, menurut Purba \& Darmawan (2018), PDB tidak memiliki pengaruh terhadap NPF di bank syariah, walaupun inflasi berpengaruh. Sedangkan menurut Syinta (2018), inflasi tidak berpengaruh terhadap financialDistress di bank syariah. Selain itu, perbedaan hasil penelitian ini juga terjadi dalam menganalisis variabel NPF, FDR, dan CAR. Di mana, menurut Syinta (2018), NPF, FDR, dan CAR berpengaruh terhadap potensi kebangkrutan, sedangkan menurut Harahap (2019), NPF, FDR, dan CAR tidak berpengaruh terhadap potensi kebangkrutan.

Dengan demikian, penelitian ini perlu untuk dilakukan karena potensi kebangkrutan dapat terjadi kapan saja dan masih terdapat perbedaan hasil penelitian dalam menentukan faktor internal dan eksternal yang mempengaruhi potensi kebangkrutan. Penelitian ini akan menjadikan variabel NPF, FDR, dan CAR sebagai faktor internal serta variabel Inflasi dan PDB sebagai faktor eksternal yang mempengaruhi potensi kebangkrutan. Penelitian ini berbeda dengan penelitian sebelumnya karena menggunakan metode Grover dalam mengukur tingkat potensi kebangkrutan, sedangkan penelitian terdahulu menggunakan metode Altman. Berdasarkan hasil penelitian yang telah dilakukan oleh Oktaviandri, Firli, dan Iradianty (2015), menunjukkan bahwa metode Grover memiliki tingkat akurasi paling tinggi dibandingkan metode Ohlson, Springate, dan Altman dalam memprediksi potensi kebangkrutan. Selain itu, menurut Nurcahyani (2015), metode Grover ini memiliki kelebihan karena mudah dalam penerapannya, menggabungkan rasio keuangan, dan rasio BEP yang terdapat dalam metode ini adalah indikator terbaik dalam menentukan terjadinya kebangkrutan.

\section{Kajian Pustaka (Font: Garamound, size 13)}

\subsection{Financial Distress}

Financial distres adalah gejala awal terjadinya kebangkrutan, dimana perusahaan mengalami kesulitan dalam memenuhi kewajibannya, sehingga terancam mengalami kebangkrutan (Aprylia, 2016). Kondisi keuangan perusahaan yang mengalami kesulitan harus segera diatasi sebelum kebangkrutan terjadi. Apabila perusahaan mengalami kondisi seperti itu, maka perusahaan harus berhati-hati karena dapat memungkinkan terjadinya kebangkrutan dan financial distress dapat menjadi pertanda awal dari kebangkrutan (Lestari et al., 2020).

\subsection{Metode Grover}

Metode Grover adalah metode yang dibuat dengan melakukan pendesainan dan penilaian ulang dari metode Altman Z-Score yang dilakukan oleh Jeffery S. Grover (Prihatini \& Sari, 2013). Berdasarkan penelitian tersebut, pada tahun 2001, Jeffery S. Grover berhasil membuat formula untuk metode Grover sebagai berikut (Prihatini \& Sari, 2013):

$$
\mathrm{G}-\text { Score }=1,650 \mathrm{X}_{1}+3,404 \mathrm{X}_{2}+0,016 \mathrm{ROA}+0,057
$$


Metode Grover memiliki kriteria skor untuk menentukan kategori perusahaan, yaitu apabila GScore $\leq-0,02$, maka perusahaan termasuk ke dalam kategori financial distress. Apabila G-Score $\geq 0,01$, maka perusahaan termasuk ke dalam kategori sehat (Prihatini \& Sari, 2013).

\subsection{Non Performing Finance (NPF)}

NPF adalah rasio yang menunjukkan kemampuan bank dalam mengelola pembiayaan bermasalah yang dimilikinya (Siamat, 2005). Rasio NPF dapat dihitung dengan membandingkan jumlah pembiayaan bermasalah dengan jumlah pembiayaan yang disalurkan, semakin tinggi besar NPF, maka kualitas pembiayaan yang dimiliki bank semakin buruk dan menimubulkan potensi kebangkrutan atau financial distress (Setyowati, 2019).

\subsection{Financing to Deposit Rasio (FDR)}

FDR adalah rasio yang menunjukkan jumlah dana pihak ketiga yang disalurkan dalam bentuk kredit atau pembiayaan (Kasmir, 2008). Apabila besar FDR semakin besar, maka tingkat likuiditas yang dimiliki bank syariah tersebut semakin rendah dan diharapkan bank syariah mendapatkan keuntungan yang tinggi (Wangsawidjaja, 2012). Akan tetapi, besar FDR yang dimiliki bank syariah tidak boleh terlalu rendah karena dapat mengganggu biaya operasional dan juga tidak boleh terlalu tinggi karena dapat menurunkan tingkat profitabilitas bank yang akan memicu munculnya financial distress (Hijriyani \& Setiawa, 2017).

\subsection{Capital Adequacy Ratio (CAR)}

Menurut Dendawijaya (2009), CAR adalah rasio yang menunjukkan aktiva bank yang berisiko, seperti pembiayaan, surat berharga, dan tagihan pada bank lain, kemudian aktiva tersebut akan ditutupi dengan modal sendiri milik bank. CAR dapat dijadikan sebagai indikator dalam mengukur kemampuan bank dalam menutupi aktiva berisikonya yang dapat menyebabkan kerugian pada bank (Dendawijaya, 2009). CAR dihitung dengan membandingkan jumlah modal sendiri dengan aktiva tertimbang menurut risiko (ATMR) dengan besar CAR paling minimal sebesar 8\% (Rianto \& Rahmawati, 2015).

\subsection{Inflasi}

Menurut Rozalinda (2014), inflasi adalah gejala yang menunjukkan kenaikan tingkatharga umum yang berlangsung secara terus-menerus. Apabila terjadi kenaikan harga hanya sementara, maka itu tidak bisa dikatakan inflasi. Inflasi terjadi karena kenaikan harga secara umum yang artinya kenaikan harga dari satu jenis barang maupun jasa tidak bisa dikatakan inflasi (Rozalinda, 2014).

\subsection{Produk Domestik Bruto (PDB)}

PDB digunakan sebagai indikator dalam mengukur pertumbuhan ekonomi di suatu negara (Arif, 2014). Peningkatan pertumbuhan PDB dapat dijadikan sebagai indikator bagi perbankan dalam menyalurkan kredit atau pembiayaannya karena PDB yang tinggi menunjukkan pendapatan rata-rata masyarakat suatu negara tersebut juga tinggi (Purba \& Darmawan, 2018).

\section{Metode Penelitian}

Metode penelitian yng dignakan dalam penelitian ini yaitu metde deskrptif kuantitatif. Data yang diteliti bersumber dari laporan keuangan tahunan Bank Umum Syariah di Indonesia periode 2014-2018, laporan Bank Indonesia (BI) mengenai inflasi yang diakses di www.bi.go.id, dan laporan Badan Pusat Statistik (BPS) mengenai PDB yang diakses di www.bps.go.id. Penelitian ini dianalsis dengan menggunakan software EViews versi 10, sedangkan hipotesis akan diuji menggnakan 
model regresi logistik dengan mengkategorikan variabel dependen, yaitukategori 0 (null)yangartinya sehat dan kategori 1 (satu) yang artinya financial distress. Dalam model regresi logistik akan dilakukan pengujian penilaian model fit dengan uji Hosmer and Lemeshow Goodness of Fit Test dan pengujian hipotesis dengan uji Likelihood Ratio Statistic dan uji Koefisien Parsial.

\section{Hasil dan Pembahasan}

\subsection{Hasil Perhitungan G-Score}

Tabel 3. Hasil Perhitungan G-Score

\begin{tabular}{|c|c|c|c|c|}
\hline BUS & Tahun & G-Score & Keterangan & Kategori \\
\hline \multirow[t]{5}{*}{ PNBS } & 2014 & 0,5929 & Sehat & 0 \\
\hline & 2015 & 0,3906 & Sehat & 0 \\
\hline & 2016 & 0,4635 & Sehat & 0 \\
\hline & 2017 & $-0,0022$ & Sehat & 0 \\
\hline & 2018 & 0,4358 & Sehat & 0 \\
\hline \multirow[t]{5}{*}{ BCAS } & 2014 & 0,6303 & Sehat & 0 \\
\hline & 2015 & 0,7476 & Sehat & 0 \\
\hline & 2016 & 0,7404 & Sehat & 0 \\
\hline & 2017 & 0,6222 & Sehat & 0 \\
\hline & 2018 & 0,6620 & Sehat & 0 \\
\hline \multirow[t]{5}{*}{ BJBS } & 2014 & 0,4564 & Sehat & 0 \\
\hline & 2015 & 0,3253 & Sehat & 0 \\
\hline & 2016 & 0,0336 & Sehat & 0 \\
\hline & 2017 & 0,1468 & Sehat & 0 \\
\hline & 2018 & 0,5911 & Sehat & 0 \\
\hline \multirow[t]{5}{*}{ BNIS } & 2014 & 0,0961 & Sehat & 0 \\
\hline & 2015 & 0,1619 & Sehat & 0 \\
\hline & 2016 & 0,1392 & Sehat & 0 \\
\hline & 2017 & 0,1189 & Sehat & 0 \\
\hline & 2018 & 0,0235 & Sehat & 0 \\
\hline \multirow[t]{5}{*}{ BRIS } & 2014 & 0,0991 & Sehat & 0 \\
\hline & 2015 & 0,1540 & Sehat & 0 \\
\hline & 2016 & 0,2207 & Sehat & 0 \\
\hline & 2017 & 0,0909 & Sehat & 0 \\
\hline & 2018 & 0,0486 & Sehat & 0 \\
\hline \multirow[t]{5}{*}{ BSM } & 2014 & 0,3925 & Sehat & 0 \\
\hline & 2015 & 0,3307 & Sehat & 0 \\
\hline & 2016 & 0,2567 & Sehat & 0 \\
\hline & 2017 & 0,2742 & Sehat & 0 \\
\hline & 2018 & 0,2744 & Sehat & 0 \\
\hline \multirow[t]{5}{*}{ BMSI } & 2014 & 0,6813 & Sehat & 0 \\
\hline & 2015 & $-1,0680$ & Financial Distress & 1 \\
\hline & 2016 & $-0,4569$ & Financial Distress & 1 \\
\hline & 2017 & 0,7428 & Sehat & 0 \\
\hline & 2018 & 0,7586 & Sehat & 0 \\
\hline
\end{tabular}




\begin{tabular}{|c|c|c|c|c|}
\hline BUS & Tahun & G-Score & Keterangan & Kategori \\
\hline \multirow[t]{5}{*}{ BSB } & 2014 & 0,2566 & Sehat & 0 \\
\hline & 2015 & 0,0260 & Sehat & 0 \\
\hline & 2016 & $-0,1767$ & Financial Distress & 1 \\
\hline & 2017 & 0,2441 & Sehat & 0 \\
\hline & 2018 & 0,1496 & Sehat & 0 \\
\hline \multirow[t]{20}{*}{ BMI } & 2014 & 0,2148 & Sehat & 0 \\
\hline & 2015 & 0,2302 & Sehat & 0 \\
\hline & 2016 & 0,2384 & Sehat & 0 \\
\hline & 2017 & 0,3075 & Sehat & 0 \\
\hline & 2018 & 0,2313 & Sehat & 0 \\
\hline & 2014 & 0,0833 & Sehat & 0 \\
\hline & 2015 & 0,3481 & Sehat & 0 \\
\hline & 2016 & 0,3691 & Sehat & 0 \\
\hline & 2017 & 0,4339 & Sehat & 0 \\
\hline & 2018 & 0,4687 & Sehat & 0 \\
\hline & 2014 & 1,3486 & Sehat & 0 \\
\hline & 2015 & 1,2273 & Sehat & 0 \\
\hline & 2016 & 1,1179 & Sehat & 0 \\
\hline & 2017 & 1,3432 & Sehat & 0 \\
\hline & 2018 & 1,2316 & Sehat & 0 \\
\hline & 2014 & 0,1466 & Sehat & 0 \\
\hline & 2015 & 0,2475 & Sehat & 0 \\
\hline & 2016 & $-0,1062$ & $\begin{array}{l}\text { Financial } \\
\text { Distress }\end{array}$ & 1 \\
\hline & 2017 & 0,2448 & Sehat & 0 \\
\hline & 2018 & 0,5824 & Sehat & 0 \\
\hline
\end{tabular}

Smber: Data diolah

Dapat dilihat bahwa terdapat 4 (empat) bank syariah yang mengalami financial distress, yaitu BSM (Bank Syariah Mandiri) pada tahun 2015 dan 2016, BSB (Bank Syariah Bukopin) pada tahun 2016, dan BVS (Bank Victoria Syariah) pada tahun 2016. Hal ini menunjukkan sisanya termasukkedalam kategorisehat, sehingga dapat dikatakan bahwa bank syariah mampu mengelola manajemen risikonya untuk memenuhi kewajibannya.

\subsection{Analisis Deskriptif}

Tabel 4. Statistik Deskriptif

\begin{tabular}{|l|c|c|c|c|c|}
\hline & NPF & FDR & CAR & INFLASI & PDB \\
\hline Mean & 5.711167 & 7171.759 & 24.53900 & 4.300000 & 5.020000 \\
\hline Maximum & 43.99000 & 424923.5 & 163.0700 & 8.400000 & 5.200000 \\
\hline Minimum & 0.000000 & 71.87000 & 11.51000 & 3.000000 & 4.800000 \\
\hline Std. Dev. & 7.471127 & 54845.62 & 21.50782 & 2.078461 & 0.133785 \\
\hline
\end{tabular}

Sumber: Data diolah dengan EViews

a. Variabel NPF memiliki rata-rata sebesar 5,72, nilai minimum sebesar 0,00 , nilai maksimum sebesar 43,99, dan standar deviasi sebesar 7,47. 
b. Variabel FDR memiliki rata-rata sebesar 7171,76 , nilai minimum sebesar 71,87 , nilai maksimum sebesar 424923,5 dan standar deviasi sebesar 54845,62.

c. Variabel CAR memiliki rata-rata sebesar 24,54 , nilai minimum sebesar 11,51 , nilai maksimum sebesar 163,07, dan standar deviasi sebesar 21,51.

d. Variabel Inflasi memiliki rata-rata sebesar 4,30, nilai minimum sebesar 3,00, nilai maksimum sebesar 8,40, dan standar deviasi sebesar 2,08.

e. Variabel PDB memiliki rata-rata sebesar 5,02, nilai minimum sebesar 4,80, nilai maksimum sebesar 5,20, dan standar deviasi sebesar0,13.

\subsection{Analisis Regresi Logistik}

\subsubsection{Uji Hosmer and Lemeshow Goodnes of Fit Test}

Tabel 5. Hosmer and Lemeshow Goodness of Fit Test

\begin{tabular}{|c|c|c|c|c|c|c|c|c|}
\hline & \multicolumn{2}{|c|}{ Quantile of Risk } & \multicolumn{2}{|c|}{ Dep $=0$} & \multicolumn{2}{|c|}{ Dep $=1$} & \multirow{2}{*}{$\begin{array}{c}\text { Total } \\
\text { Obs }\end{array}$} & \multirow{2}{*}{$\begin{array}{r}\text { H-L } \\
\text { Value }\end{array}$} \\
\hline & Low & High & Actual & Expect & Actual & Expect & & \\
\hline 1 & 2.E-28 & 8.E-28 & 6 & 6.00000 & 0 & $2.3 \mathrm{E}-27$ & 6 & $2.3 \mathrm{E}-27$ \\
\hline 2 & 1.E-27 & 2.E-27 & 6 & 6.00000 & 0 & $9.4 \mathrm{E}-27$ & 6 & $9.4 \mathrm{E}-27$ \\
\hline 3 & 2.E-06 & 4.E-05 & 6 & 5.99987 & 0 & 0.00013 & 6 & 0.00013 \\
\hline 4 & 6.E-05 & 0.0006 & 6 & 5.99901 & 0 & 0.00099 & 6 & 0.00099 \\
\hline 5 & 0.0011 & 0.0043 & 6 & 5.98331 & 0 & 0.01669 & 6 & 0.01674 \\
\hline 6 & 0.0048 & 0.0067 & 6 & 5.96659 & 0 & 0.03341 & 6 & 0.03359 \\
\hline 7 & 0.0071 & 0.0104 & 6 & 5.95026 & 0 & 0.04974 & 6 & 0.05016 \\
\hline 8 & 0.0149 & 0.0404 & 6 & 5.85836 & 0 & 0.14164 & 6 & 0.14506 \\
\hline 9 & 0.0517 & 0.1341 & 6 & 5.44595 & 0 & 0.55405 & 6 & 0.61042 \\
\hline \multirow[t]{2}{*}{10} & 0.1576 & 0.9951 & 2 & 2.80028 & 4 & 3.19972 & 6 & 0.42886 \\
\hline & & Total & 56 & 56.0036 & 4 & 3.99637 & 60 & 1.28595 \\
\hline \multicolumn{3}{|c|}{ H-L Statistic } & 1.2860 & & \multicolumn{2}{|c|}{ rob. Chi-Sq(8) } & 0.9957 & \\
\hline \multicolumn{3}{|c|}{ Andrews Statistic } & 48.2387 & & \multicolumn{2}{|c|}{ rob. Chi-Sq(10) } & 0.0000 & \\
\hline
\end{tabular}

Sumber: Data diolah dengan EViews

Dapat dilihat bahwa besar HL Statistic adalah sebesar 1,29 dengan probabilitas Chi-Square lebih dari 0,05 , yaitu sebesar 0,996 yang artinya $\mathrm{H}_{0}$ diterima dan memiliki makna model yang dihipotesiskan fit dengan data.

\subsubsection{McFadden R-Square}

Tabel 6. McFadden R-Squared

\begin{tabular}{lllr}
\hline \hline McFadden R-squared & 0.627927 & Mean dependent var & 0.066667 \\
S.D. dependent var & 0.251549 & S.E. of regression & 0.184766 \\
Akaike info criterion & 0.382264 & Sum squared resid & 1.843470 \\
Schwarz criterion & 0.591698 & Log likelihood & -5.467918 \\
Hannan-Quinn criter. & 0.464185 & Deviance & 10.93584 \\
Restr. deviance & 29.39160 & Restr. log likelihood & -14.69580 \\
LR statistic & 18.45577 & Avg. log likelihood & -0.091132 \\
Prob(LR statistic) & 0.002426 & & \\
\hline
\end{tabular}




\begin{tabular}{lrll}
\hline Obs with Dep $=0$ & 56 & Total obs & 60 \\
Obs with Dep $=1$ & 4 & & \\
\hline
\end{tabular}

Sumber: Data diolah dengan Eviews

Tabel di bawah ini menjelaskan bahwa besar McFadden R-Squared adalah sebesar 0,6279 atau $62,79 \%$ yang memiliki arti bahwa sebesar $62,79 \%$ variabel NPF, FDR, CAR, Inflasi, dan PDB dapat memprediksi variabel financial distress, sedangkan sisanya dapat dijelaskan oleh variabel lain di luar model.

4.3.3. Uji Likehood Ratio Statistic (LR Stat)

Tabel 7. Likehood Ratio Statistik (LR Stat)

\begin{tabular}{|c|c|c|c|}
\hline McFadden R-squared & 0.627927 & Mean dependent var & 0.066667 \\
\hline S.D. dependent var & 0.251549 & S.E. of regression & 0.184766 \\
\hline Akaike info criterion & 0.382264 & Sum squared resid & 1.843470 \\
\hline Schwarz criterion & 0.591698 & Log likelihood & -5.467918 \\
\hline Hannan-Quinn criter. & 0.464185 & Deviance & 10.93584 \\
\hline Restr. deviance & 29.39160 & Restr. log likelihood & -14.69580 \\
\hline LR statistic & 18.45577 & Avg. log likelihood & -0.091132 \\
\hline Prob(LR statistic) & 0.002426 & & \\
\hline Obs with Dep $=0$ & 56 & Total obs & 60 \\
\hline Obs with Dep=1 & 4 & & \\
\hline
\end{tabular}

Sumber: Data diolah dengan EViews

Dapat dilihat bahwa besar LR Statistik adalah sebesar 18,46 dengan probabilitas LR Statistik kurang dari 0,05 , yaitu sebesar 0,002 yang berarti $\mathrm{H}_{0}$ ditolak dan $\mathrm{Ha}$ diterima dan memiliki makna bahwa NPF, FDR, CAR, Inflasi, dan PDB secara simultan berpengaruh terhadap financial distress pada Bank Umum Syariah.

\subsubsection{Uji Koefisien Parsial}

Tabel 8. Koefisien Parsial

\begin{tabular}{crrrr}
\hline \hline Variable & Coefficient & Std Error & z-Statistic & Prob \\
\hline \hline C & 80.34218 & 43.61303 & 1.842160 & 0.0655 \\
NPF & 0.228198 & 0.053583 & 4.258775 & 0.0000 \\
FDR & $3.46 \mathrm{E}-06$ & 0.000300 & 0.011538 & 0.9908 \\
CAR & -0.046980 & 0.064926 & -0.723595 & 0.4693 \\
INFLASI & -11.16002 & 3.930441 & -2.839380 & 0.0045 \\
PDB & -9.800703 & 6.781691 & -1.445171 & 0.1484 \\
\hline
\end{tabular}

Sumber: Data diolah dengan EViews

Dapat dilihat hasil pengujian hipotesis yang menunjukkan pengaruh antara NPF, FDR, CAR, Inflasi, dan PDB terhadap Financial Distress pada Bank Umum Syariah di Indonesia. Berikut penjelasannya, yaitu:

NPF berpengaruh signifikan terhadap financial distress pada Bank Umum Syariah dengan $p$ value $<0,05$, yaitu 0,00 yang artinya $\mathrm{H}_{0}$ ditolak dan $\mathrm{H}_{\mathrm{a}}$ diterima. 
FDR tidak berpengaruh signifikan terhadap financial distress pada Bank Umum Syariah dengan p-value $>0,05$, yaitu 0,99 yang artinya $\mathrm{H}_{0}$ diterima dan $\mathrm{H}_{\mathrm{a}}$ ditolak.

CAR tidak berpengaruh signifikan terhadap financial distress pada Bank Umum Syariah dengan p-value $>0,05$, yaitu 0,47 yang artinya $\mathrm{H}_{0}$ diterima dan $\mathrm{H}_{2}$ ditolak.

Inflasi berpengaruh signifikan terhadap financial distress pada Bank Umum Syariah dengan $p$ value $<0,05$, yaitu 0,004 yang artinya $\mathrm{H}_{0}$ ditolak dan $\mathrm{H}_{2}$ diterima.

PDB tidak berpengaruh signifikan signifikan terhadap financial distress pada BankUmum Syariah dengan p-value $>0,05$, yaitu 0,15 yang artinya $\mathrm{H}_{0}$ diterima dan $\mathrm{H}_{\mathrm{a}}$ ditolak.

\subsection{Pembahasan}

\subsubsection{Pengaruh NPF terhadap Financial Distress pada Bank Umum Syariah}

Hasil penelitian ini menunjukkan bahwa NPF berpengaruh signifikan terhadap financial distress pada bank syariah dengan koefisien bertanda positif yang artinya semakin tinggi NPF, maka semakin tinggi juga probabilitas terjadinya financial distress. Menurut Dendawijaya (2009), NPF yang tinggi menunjukkan bahwa jumlah pembiayaan bermasalah pada bank tersebut juga tinggi, sehingga akan menurunkan laba bank dan memicu munculnya financial distress. Hasil penelitian ini sesuai dengan penelitian yang telah dilakukan oleh Putri Sholikati (2018) yang menunjukkan bahwa NPF berpengaruhsignifikan terhadap financial distress.

\subsubsection{Pengaruh FDR terhadap Financial Distress pada Bank Umum Syariah}

Hasil penelitian ini menunjukkan bahwa FDR tidak berpengaruh signifikan terhadap financial distress pada bank syariah karena besar FDR selama periode penelitian dalam keadaan sehat yang berarti kemampuan likuiditas yang dimiliki bank syariah sudah cukup baik. Menurut Dendawijaya (2009), ketika besar FDR rendah, maka kemampuan likuiditas bank semakin baik, karena bank mampu menjaga dana yang disalurkan dalam bentuk pembiayaan, sehingga tidak akan memicu terjadinya financial distress. Hasil penelitian ini sesuai dengan penelitian yang dilakukan oleh Tri Mugiarti dan Muji Mranani (2019) yang menunjukkan bahwa FDR tidak berpengaruh signifikan terhadap financial distress.

\subsubsection{Pengaruh CAR terhadap Financial Distress pada Bank Umum Syariah}

Hasil penelitian ini menunjukkan bahwa CAR tidak berpengaruh signifikan terhadap financial distress pada bank syariah yang berarti kemampuan bank dalam menutupi aktiva berisikonya sudah baik. Hal ini dikarenakan besar CAR pada bank syariah selama periode penelitian ini sudah lebih dari $8 \%$ yang artinya CAR pada bank syariah dalamkeadaan sangatsehat. Menurut Sholikati (2018), CAR yang tinggi mengindikasikan bahwa bank mampu memenuhi biaya kegiatan operasionalnya dan bank memiliki struktur modal yang baik, sehingga tidak akan memicu terjadinya financial distress. Hasil penelitian ini sesuai dengan penelitian yang dilakukan oleh Putri Sholikati (2018) yang menunjukkan bahwa CAR tidak berpengaruh signifikan terhadap financial distress.

\subsubsection{Pengaruh Inflasi terhadap Financial Distress pada Bank Umum Syariah}

Hasil penelitian ini menunjukkan bahwa inflasi berpengaruh signifikan terhadap financial distress pada bank syariah dengan koefisien bertanda negatif. Hal ini menunjukkan arah negatif yang berarti semakin tinggi inflasi, maka semakin rendah probabilitas terjadinya financial distress karena tren inflasi selama periode penelitian mengalami penurunan yang signifikan, yaitu dari 8,4\% di tahun 2014 menjadi 3,1\% di tahun 2018. Hasil penelitian ini sesuai dengan penelitian yang telah dilakukan oleh Nova Shenni Purba dan Ari Darmawan (2018) yang menunjukkan bahwa inflasi berpengaruh signifikan terhadap pembiayaan bermasalah. 


\subsubsection{Pengaruh PDB terhadap Financial Distress pada Bank Umum Syariah}

Hasil penelitian ini menunjukkan bahwa PDB tidak berpengaruh signifikan terhadap financial distress pada bank syariah. Menurut Purba \& Darmawan (2018), ketika pendapatan per kapita masyarakat meningkat, sifat konsumtif masyarakat akan meningkat pula karena kebutuhan yang cenderung meningkat, sehingga masyarakat akan mengesampingkan kewajibannya untuk mengembalikan pinjaman kepada bank, sehingga pertumbuhan PDB tidak akan memicu terjadinya financial distress di bank syariah.

\section{Penutup (Font: Garamound, size 13)}

Berdasarkan hasil analisis yang telah dibahas dalam penelitian ini, maka dapat ditarik. kesimpulan sebagai berikut, yaitu:

a. Bedasarkan perhitungan dengan metode Grover, terdapat 4 (empat) Bank Umum Syariah yang mengalami financial distress selama periode 2014-2018, yaitu Bank Syariah. Mandiri di tahun 2015 dan 2016, Bank Syariah. Bukopin di tahun 2016, dan Bank Victoria Syariah di tahun 2016.

b. Pengaruh variabel independen faktor internal secara parsial, yaitu:

1) Non Performing Financing (NPF) berpengaruh signifikan dengan arah positif terhadap Financial Distress pada Bank Umum Syariah periode 2014-2018 yang menunjukkan bahwa NPF yang tinggi akan menurunkan laba bank yang memicu terjadinya financial distress.

2) Financing to Deposit Ratio (FDR) tidak berpengaruh signifikan terhadap Financial Distress pada Bank Umum Syariah periode 2014-2018. Hal ini mengindikasikan bahwa sebanyak apapun dana yang disalurkan tidak akan memicu terjadinya financial distress karena selama periode penelitian bank syariah memiliki kemampuan likuiditas yang cukup baik.

3) Capital Adequacy Ratio (CAR) tidak berpengaruh signifikan terhadap Financial Distress pada. Bank Umum Syariah periode 2014-2018. Hal ini mengindikasikan. bahwa bank syariah sudah mampu membiayai kegiatan operasionalnya dan memiliki strukturmodal yang baik, sehingga tidak akan memicu terjadinya financial distress.

c. Pengaruh variabel independen faktor eksternal secara parsial,yaitu:

1) Inflasi berpengaruh signifikan dengan arah negatif terhadap Financial Distress pada Bank Umum Syariah selama periode 2014-2018 yang menunjukkan bahwa inflasi yang tinggi akan menurunkan peluang terjadinya financial distress karena selama periode penelitian tren inflasi mengalami penurunan yang signifikan.

2) Produk Domestik Bruto (PDB) tidak berpengaruh signifikan terhadap Financial Distress pada Bank Umum Syariah periode2014-2018. Hal ini mengindikasikan bahwa meningkatnya pendapatan masyarakat tidak selalu diikuti oleh penurunan peluang terjadinya financial distress karena masyarakat akan memenuhi terlebih dahulu kebutuhannya dibandingkan kewajibannya kepada banksyariah.

Secara simultan, seluruh variabel independen adalah NPF, FDR, CAR, Inflasi, dan PDB berpengaruh terhadap Financial Distress pada Bank Umum Syariah periode 2014- 2018.

Berdasarkan penelitian yang telah dilakukan, maka terdapat beberapa saran yang peneliti akan sampaikan, yaitu:

a. Bagi perusahaan, disarankan tetap menjaga nilai NPF pada batas kewajaran karena NPF dapat menjadi early warning system dalam terjadinya financial distress. Selain itu, perusahaan juga harus memperhatikan kondisi faktor eksternal, yaitu kondisi inflasi di Indonesia karena dapat menjadi faktor yang memicu terjadinya financial distress pada bank syariah.

b. Bagi calon nasabah, disarankan untuk melihat terlebih dahulu kondisi bank syariah sebelum 
menanamkan dananya, karena bisa jadi bank tersebut berpotensi mengalami financial distress.

c. Bagi peneliti selanjutnya, disarankan untuk memperpanjang periode waktu dan objek penelitian yang akan dianalisis dan menggunakan variabel lain yang kemungkinan memiliki pengaruh terhadap financial distress pada bank syariah karena besar McFadden R-Square menunjukkan nilai sebesar $62,79 \%$ dan sisanya sebesar $37,21 \%$ dijelaskan oleh variabel lain, sehingga dapat dijadikan perbandingan dengan penelitian sebelumnya dan diperoleh kondisi financial distress pada bank syariah denganlebih rinci.

\section{Daftar Pustaka}

Amin, R. A. (2004). Bank Syariah Sebagai Solusi Berkeadilan Dan Berkerakyatan. www.google.com/bank-islam.html

Aprylia, C. (2016). Analisis Potensi Financial Distress Dengan Metode Altman Z-Score Pada Bank Umum Syariah Di Indonesia Periode Tahun 2010-2014 [Skripsi]. Universitas Islam Negeri Syarif Hidayatullah Jakarta.

Arif, D. (2014). Pengaruh Produk Domestik Bruto, Jumlah Uang Beredar, Inflasi, Dan BI Rate Terhadap Indeks Harga Saham Gabungan Di Indonesia. Jurnal Ekonomi Bisnis, 10(3).

Dendawijaya, L. (2009). Manajemen Perbankan. Ghalia Indonesia.

Harahap, R. S. (2019). Analisis Pengaruh Tingkat Kesehatan Bank Syariah Berdasarkan Risk Based Bank Rating Dalam Perbankan Syariah Di Indonesia [Skripsi]. Universitas Sumatera Utara.

Hijriyani, N. Z., \& Setiawa. (2017). Analisis Profitabilitas Perbankan Syariah di Indonesia sebagai Dampak dari Efisiensi Operasional. Jurnal Kajian Akuntansi, 1(2).

Kasmir. (2008). Bank Dan Lembaga Kenangan Lainnya Edisi Revisi. PT. Raja Grafindo Persada. Kuncoro, M., \& Suhardjono. (2011). Manajemen Perbankan TeoriDan Aplikasi.BPFE.

Lestari, H. T., Tripuspitorini, F. A., \& Setiawan. (2020). Risk Profile, Good Corporate Governance, Earning, and Capital dalam Memprediksi Financial Distress pada Bank Umum Syariah di Indonesia. Jurnal Akuntansi \& Ekonomi FE UN PGRI Kediri, 5(2).

Machmud, A., \& Rukmana. (2010). Bank Syariah Teori, Kebijakan dan Studi Empiris di Indonesia.

Muhammad. (2005). Bank Syariah Problem dan Prospek Perkembangan di Indonesia. Penerbit Graha Ilmu.

Nurcahyani, W. (2015). Studi Komparatif Model Z-Score Altman, Springate, Dan Zmijewski Dalam Mengindikasikan Kebangkrutan Perusahaan Yang Terdaftar Di BEI [Skripsi]. Universitas Negeri Padang.

Oktaviandri, A., Firli, A., \& Iradianty, A. (2015). Analisis Prediksi Kebangkrutan Dengan Model Altman, Springate, Ohlson, Dan Grover Pada Perusahaan Di Sektor Pertanian Bursa Efek Indonesia Periode 2011-2015. Majalah Ilmiah UNIKOM, 15(1).

Prihatini, N. M. E. D., \& Sari, M. M. R. (2013). Analisis Prediksi Kebangkrutan Dengan Model Grover, Altman Z-Score, Springate, Dan Zmijewski Pada Perusahaan Food And Beverage Di BEI. E-Jurnal Akuntansi Universitas Udayana,5(2).

Purba, N. S., \& Darmawan, A. (2018). Pengaruh Pertumbuhan Produk Domestik Bruto Dan Inflasi Terhadap Non Performing Finance Bank Syariah (Studi Pada Bank Umum Syariah Di Indonesia Periode 2014-2016). Jurnal Administrasi Bisnis, 61(2).

Rianto, M. N., \& Rahmawati, Y. (2015). Manajemen Risiko Perbankan Syariah. UIN PRESS.

Rivai, V., \& Dkk. (2007). Bank And Financial Institution Management: Convention And Sharia System. PT. Raja 
Grafindo Persada.

Rozalinda. (2014). Ekonomi Islam: Teori Dan Aplikasinya Pada Aktivitas Ekonomi. PT. Grafindo Persada.

Setyowati, D. H. (2019). Analisis Kinerja Keuangan Bank Umum Syariah sebagai Dampak Inefisiensi Operasional. Jurnal Maps (Manajemen Perbankan Syariab), 3(1).

Sholikati, P. (2018). Analisis Pengaruh RGEC Terhadap Financial Distress Bank Umum Syariah Di Indonesia [Skripsi]. Universitas Mubammadiyah Surakarta.

Siamat, D. (2005). Manajemen Lembaga Kenangan Indonesia. Fakultas Ekonomi Universitas Indonesia.

Syinta, N. (2018). Faktor Internal dan Eksternal Yang Mempengaruhi Potensi Kebangkrutan Bank Umum Syariah Di Indonesia (Metode Altman Z-Score Modifikasi) [Skripsi]. UIN Syariah Jakarta.

Wangsawidjaja. (2012). Pembiayaan Bank Syariah. PT. Gramedia Pustaka Utama. 